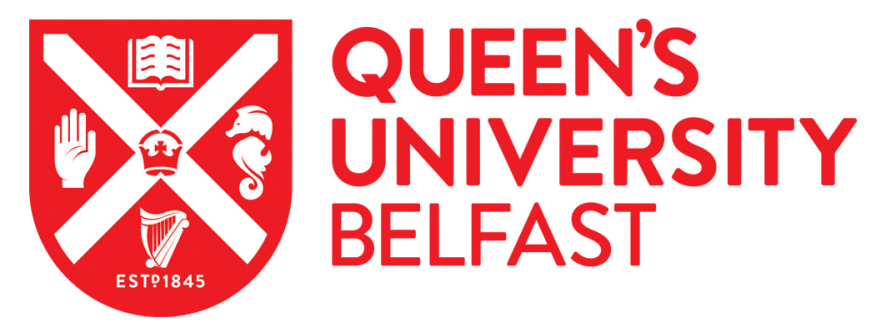

\title{
Parental leave regulations and the persistence of the male breadwinner model: Using fuzzy-set ideal type analysis to assess gender equality in an enlarged Europe
}

Ciccia, R., \& Verloo, M. (2012). Parental leave regulations and the persistence of the male breadwinner model:

Using fuzzy-set ideal type analysis to assess gender equality in an enlarged Europe. Journal Of European Social Policy, 22(5), 507-528. https://doi.org/10.1177/0958928712456576

Published in:

Journal Of European Social Policy

Document Version:

Peer reviewed version

Queen's University Belfast - Research Portal:

Link to publication record in Queen's University Belfast Research Portal

Publisher rights

Copyright 2012 the author.

\section{General rights}

Copyright for the publications made accessible via the Queen's University Belfast Research Portal is retained by the author(s) and / or other copyright owners and it is a condition of accessing these publications that users recognise and abide by the legal requirements associated with these rights.

Take down policy

The Research Portal is Queen's institutional repository that provides access to Queen's research output. Every effort has been made to ensure that content in the Research Portal does not infringe any person's rights, or applicable UK laws. If you discover content in the

Research Portal that you believe breaches copyright or violates any law, please contact openaccess@qub.ac.uk. 


\title{
Parental Leave Regulations and the Persistence of the Male Breadwinner Model: Using Fuzzy Set Ideal Type Analysis to Assess Gender Equality in an Enlarged Europe
}

\author{
Published in the Journal of European Social Policy 22(5) 507-528
}

\begin{abstract}
This paper uses fuzzy-set ideal type analysis to assess the conformity of European leave regulations to four theoretical ideal typical divisions of labour: male breadwinner, caregiver parity, universal breadwinner and universal caregiver. In contrast to the majority of previous studies, the focus of this analysis is on the extent to which leave regulations promote gender equality in the family and the transformation of traditional gender roles. The results of this analysis demonstrate that European countries cluster into five models that only partly coincide with countries' geographical proximity. Secondly, none of the countries considered constitutes a universal caregiver model, while the male breadwinner ideal continues to provide the normative reference point for parental leave regulations in a large number of European states. Finally, we witness a growing emphasis at the national and EU levels concerning the universal breadwinner ideal, which leaves gender inequality in unpaid work unproblematized.
\end{abstract}

Keywords: leave, gender equality, Europe, fuzzy sets, comparative, care work 


\section{Introduction}

National leave policies are rather complex objects of investigation. Not only do they differ on a number of dimensions, but they incorporate multiple objectives, including maternal and infant health, economic support to families, children's well-being, fertility, female employment and gender equality (Kamerman and Moss, 2009). In spite of this, research on parental leave has largely focused on its relation to maternal employment (Baker and Milligan, 2008; Gornick et al., 1997; Hofferth and Curtin, 2006; Pronzato, 2009; Ruhm, 1998; Spiess and Wrohlich, 2008). These studies show that short leaves generally have a positive influence on female employment by discouraging exit from the labour market following childbirth. In contrast, a common argument against long leaves is that they are normally used by conservative governments to lure women into full-time motherhood with potentially catastrophic consequences on their career prospects and earnings (Morgan and Zippel, 2003). Accordingly, welfare states' desire to reduce unemployment is sometimes mentioned as one of the rationales behind the introduction of leave facilities (Moss and Deven, 1999).

More recently, a growing number of authors have stressed the potential of leave policy for gender equality (Ellingsaeter and Leira, 2006; Gornick and Meyers, 2003; Ray et al., 2010). By instituting entitlements to job-protected periods off from work, leave regulations establish an albeit temporary - primacy of the demands of social/biological reproduction over those of the workplace (Leira, 2002). In this sense, they represent remarkable examples of state intervention in the internal organization of the family and can yield transformative effects in the ways in which mothers and fathers share work and childcare. This is apparent in the efforts of several European countries to expand fathers' use of leave through the introduction of quotas that reserve part of the leave to men on a 'use or lose' basis (Lammi-Taskula, 2006). This inclusion of fathers as well as mothers among those entitled to care time simultaneously challenges norms about 'good' fatherhood and organizational work cultures. Therefore, leave facilities are distinct from other childcare related measures in the sense that they can actually attract non-carers into care.

Leave policies have been described both as the product of conservative anti-feminist politics and as a promising avenue to diminish gender inequality in domestic labour. This state of confusion in current research appears partly related to the complex and continuously changing nature of leave regulations, which often leads to overly detailed policy descriptions and little systematization of comparative knowledge. To a larger extent, however, this outcome derives from the prevailing focus of comparative analyses on the generosity of leave provisions, usually defined as some combination of leave length and level of benefits. And yet, based on these measures, the best of all possible worlds would be reached when individuals (mothers) were highly rewarded to stay at home indefinitely to raise their children. This outcome would hardly be conceived as one advancing gender equality. In this paper we argue that, by conflating different aspects -time and money- of leave provisions, prior research has lost sight of the different ways in which they may combine to describe different ideals divisions of paid and unpaid work. It should also be said that generous leaves would not in themselves be so harmful for gender equality if they were not overwhelmingly taken by women, thereby reinforcing traditional gender roles (Bruning and Plantenga, 1999). Unfortunately, the concept of generosity does not address this dimension. This article overcomes these limits of previous research by advancing a theoretical framework and empirical measures of the gender equality implications of different leave policy designs.

In this paper we use fuzzy set ideal type analysis to assess the conformity of European countries' leave regulations to four theoretical models of divisions of labour -male breadwinner, 
caregiver parity, universal breadwinner, universal caregiver (Fraser, 1994). In contrast to the majority of previous studies, we take into account both gender equality and the generosity of leave policies, and distinguish generosity in terms of time and money. Moreover, the use of ideal type analysis (Weber, 1949) allows us to go beyond the simple classification and ranking of nations, and higlight which conceptions of 'normal' gender roles and gender (in)equality are implied by different combinations of these dimensions. Finally, this study considers a large and coherent group of countries -thirty European countries and the European Union- in order to assess similarities and differences across the region.

\section{Theoretical discussion}

Most welfare state scholars would maintain that welfare states are about making societies more egalitarian and that class and gender are among the most salient divisions in modern industrialized countries. Still, the primacy of class differences and struggles in the dominant historical accounts of welfare states' formation concealed their differential consequences for inequalities in terms of class and gender (Korpi, 2000). A substantial amount of feminist scholarship has been therefore dedicated to gendering welfare state research. These studies demonstrate that those same programmes developed to protect workers from the vagaries of the market, sometimes acted to reproduce and reinforce other forms of complex inequalities originating from the unequal distribution of power and care responsibilities within the household (Crompton, 1999; Lewis, 1992; Lister, 1997; O'Connor et al., 1999; Orloff, 1993; Sainsbury, 1996)

Growing female employment and the unravelling of the gender contract of the Golden age of welfare states have given new impulse to comparative research on the social organization of care (Anttonen and Sipilä, 1996; Bettio and Plantenga, 2004; Crompton, 2006; Gornick and Meyers, 2003; Knijn and Kremer, 1997; Leira, 1992, 2002). At the centre of this debate is the double movement of both women and care from the private household sphere to the public sphere of formal markets. Therefore, childcare is transformed from a private duty of families to a collective responsibility on the basis of which working parents can make claims on the welfare state to facilitate a more equal division of paid work. In this sense, the use of concepts such as 'defamilialization' (Leitner, 2003; Lister, 1997) is deliberatively aimed at comparing national variations in the distribution of caring responsibilities between the state/market and the family. However, these detailed analyses of policy architectures are seldom accompanied by an equal attention to the role of actors different from the state (e.g. men) and power dynamics going on outside the public sphere (e.g. within the household).

The necessity to look into the household division of unpaid work stems from the existence of inherent limits to the commodification of care and its value for overall societies. The current emphasis on formal provisioning neglects that the relation of care is always one of mutual dependence (Tronto, 1993). The nature of care itself entails the creation of emotional bonds and intimate relations between those giving and receiving care that go beyond mere physical presence or the performance of activities intended to the deliver a service. As a result, formal facilities can never eradicate individuals' caring duties but only relieve them to a certain extent and just for the time they are in paid employment. Further limits to the commodification of care stem from the existence of different cultural ideals about the 'proper way' to care that may only partly fit with its externalization outside the household (Kremer, 2007). For all these reasons, there is always a 
certain -not negligible- amount of care which can only be performed informally by household members.

Further issues concern the value that societies attribute to care work. As women come to be increasingly defined as workers, care activities are alternatively presented as an obstacle to women's employment and a burden for families squeezed between the demands of the workplace and the home. This re-conceptualization of care manifestly ignores its enormous importance both in terms of reproductive work and as a source of personal fulfilment that should be equally accessible to women and men. As discussed by Knijn and Kremer (1997), childcare rights comprise not only negative entitlements -the right not to be full-time carers- but also positive ones -the right to time for care. Concerns about the de-valuing of care are also extremely important in view of the increased importance of migrant domestic workers in many Western societies (Lutz, 2008). The low symbolic and monetary value attached to domestic activities in modern societies relates to their historical isolation in the domestic economy during the industrialization era. Accordingly, their shift back to the realm of paid labour often generates jobs that lie at the bottom of the occupational structure, and which are disproportionally carried out by migrant women. Therefore, a higher involvement of men in caregiving, by contributing to the re-valuing of care, could also impede that care jobs become the site of discrimination for diverse groups of individuals along class, gender and racial/ethnic divisions.

In the last decades, a growing number of scholars has highlighted the potential of leave policies to transform the division of labour within the family. Compared to childcare services which can only indirectly promote a more equal distribution of reproductive work by reducing families' (women's) care load, parental leave legislation creates immediate incentives/disincentives for fathers to participate in childcare, thus influencing more directly the ways in which men and women come to share not only paid work but also childcare (Leira, 2002; Leitner, 2003). In this sense, the different configurations of opportunities/constrains embedded in leave legislation can be expected to structure preferences and behaviors of individuals (Sundström and Duvander, 2002). For instance, research shows that fathers' use of leave can have long-lasting effects on their subsequent involvement in childcare (Haas and Hwang, 2008). Moreover, leave regulations not only offer parents entitlements to spend time with their children, but also create norms about good motherhood and fatherhood, and as such can contribute to transform the social construction of 'normal' gender roles (Leira, 2002). In this sense, Gornick and Meyers (2008) have advanced leave regulations as a fundamental ingredient of the policy package expected to support a dual earnercarer society -a societal ideal able to reconcile in an egalitarian manner the interests of men, women, and children. In spite of growing attention to gender equality in leave regulations, few empirical studies have systematically compared the extent to which national leave regulations promote the transformation of traditional gender roles (Bruning and Plantenga, 1999; Ferrarini, 2006; Haas, 2003; Wall, 2007).

In some recent works, Gornick and Meyer (2003) and Ray et al. (2010) have analyzed the gender structure of leave regulations across a number of high-income countries by developing an additive index measuring the extent to which men and women are granted equal rights and the strength of incentives for fathers' use of leave. However, the focus of these studies remains not on policy models but on the (cor)relation between single dimensions of leave regulations -generosity and gender equality. Accordingly, the authors conclude that in any given country leave policies can be generous or gender egualitarian, or both, or neither (Ray et al., 2010: 207). Yet, index and correlation measures can be misleading when classyfing countries into different types, especially 
when considering conceptually distinct and antithetical dimensions (Hudson and Kuhner, 2010). For instance, the United States scores as a middle-performer on Ray et al. gender equality index in spite of very limited leave facilities. Nevertheless, an equal distribution of leave rights that derives from similarly poor entitlements for men and women does little to advance gender equality. Given the lack of theoretical assumptions on the ways in which gender equality and generosity can be connected, previous research leaves a number of important questions unaddressed. Why do some generous leave policies (re)produce gender inequality while others that are equally generous don't? What are the gender implications of these combinations?

In this paper, we argue that cross-country differences in leave regulations can be better understood in terms of configurations of conceptually rooted policy dimensions highlighting different conceptions of gender equality. More specifically, this paper aims: 1) to connect leave research with theoretical work on models of division of labour (Fraser, 1994), and 2) to map differences in parental leave institutions across European countries according to these theoretical models. Thus, we concentrate on normative frameworks, not their actual impact on gender equality. In the next section we will discuss four ideal types of gender division of labour, and their implications for leave policy design. The following sections illustrate the data, method and policy dimensions used to evaluate European countries conformity to these models. Thereafter, we present the empirical findings and highlight commonalities across European countries.

\section{Ideal typical models of gender division of labour}

Nancy Fraser is one of the first authors to have raised the question of how to value and redistribute more equally not only formal work but also informal care activities, while dealing explicitly with the concept of gender equality. Does women's attainment of equality require that women be treated the same as men or rather that women's differences be recognized and provided for? In an influential article (1994), Fraser argued that the solution to this long standing feminist debate lies in the ideal of a universal caregiver society. In such a world, men and women would just as equally engage in paid and unpaid work. Based on her pioneering work, several autors (Crompton, 1999; Gornick and Meyers, 2003; Lewis and Giullari, 2005; Morgan, 2008) have pointed out at alternative arrangements to the traditional roles envisioned in the male breadwinner ideal. Differences between these models concern the extent to which men and women engage in work and care, the degree to which carers are financially independent, and the ways in which gender equality is conceptualized. Drawing on this litterature, it is possible to identify four ideal typical divisions of labour:

- The male breadwinner model (MB) is based on a traditional division of gender roles with men primarily responsible for earning an income apt to support the whole family and women essentially in charge of domestic/reproductive activities. A good father provides for his family and may help out occasionally but is not expected to take direct responsibility in childcare. Women, instead, depend financially on their husbands' income or on entitlements to welfare state benefits derived from their status as wives and mothers (gender difference).

- The caregiver parity model (CGP) also maintains traditional gender roles but values them equally. Women remain responsible for childcare but the state recognizes and generously 
rewards their unpaid work by means of care allowances and other benefits (equally rewarded gender difference).

- The universal breadwinner (UB), or adult-worker model (Lewis and Giullari, 2005), assumes that both men and women are fully engaged in the labour market. In order for women to be in employment just as men, care must be outsourced to the state/market spheres. Gender equality is defined as gender sameness and implies that families should be freed from care work (equal obligations gender sameness).

- The universal caregiver (UC) or earner/carer model (Crompton, 1999; Gornick and Meyers, 2003 ) is the only model that aims at transforming gender roles inside and ouside the labour market by inducing "men to become more like most women are now - that is, people who do primary care" (Fraser, 1994: 611). Since men and women are supposed to engage equally in work and care, care is a responsibility of both families and public actors (state, employers). However, the responsibility for the care of very young children is placed primarily in the home. Finally, care and work are considered equally valuable activities (transformative gender sameness).

Each of these models leads to a different configuration of leave policies (table 1). Both the $\mathrm{MB}$ and the CGP models offer long periods of absence from work, but those periods are essentially intended for mothers since, unlike men, they are primarily conceived as carers and only marginally as workers (i.e. concentration of leave on the mother). Only the CGP model, however, values these periods and offers mothers monetary compensation. The defining characteristic of the UB model lies instead in the short duration of entitlements. As parents are supposed to be in employment, regulations provide only compulsory maternity leave intended to protect the health of the mother and the newborn, while also securing women's rights to participate in the labour market. If both parents enjoy few leave rights, those few rights are still essentially targeted on mothers. Family caregiving is also generally unvalued, but some payment (not higher than sickness benefit level) can be granted since the brevity of entitlements reduces the risk of disincentives to work. The UC model is distinct from the others in that it recognizes the equal right of mothers and fathers to time for care (i.e. equal distribution of leave), and these periods are valued as equal to work. Since this model aims to transform traditional gender roles, this is the only ideal type that actively promotes fathers' use of leave.

[table 1]

\section{Data and method}

This paper draws on statutory leave regulations data gathered within the EU project QUING ${ }^{1}$. The focus of this analysis is on maternity, paternity and parental leave policies in EU-27 countries and Norway, Iceland, Switzerland as of March 2010. These legislations grant parents the right to periods of employment-protected absence from work following the birth or adoption of a child. Some form of finanicial support is also usually available during these periods. Since the European 
Union has set minimum standards with regard to leave provisions, we also included in this analysis the Pregnant Worker Directive $(92 / 85 / \mathrm{EC})^{2}$, and the recently revised Parental Leave Directive (2010/18/EU), which establishes an individual right to four months of leave. Policies considered in this paper essentially concern working parents, even though regulations may also provide limited benefits for non-working or self-employed individuals. Given that in several countries different arrangements are possible according to, for instance, parents' employment sector (public or private), we follow Ray et al. (2010) and consider regulations providing the least generous provisions. Nevertheless, the scope of these provisions varies considerably across countries (Bruning and Plantenga, 1999). In many countries eligibility is restricted according to parents' employment history or through income thresholds, while collective agreements and individual employers may supplement the basic entitlements laid out in statutory regulations. Limited availability of reliable comparative data prevents us from considering these aspects. Still, the exclusion of this information is acceptable, considering the focus of this paper on norms about the gender division of labour, and not on actual outcomes of leave regulations.

\section{Fuzzy-set ideal type analysis}

In this paper, we use fuzzy set ideal type analysis (FSITA) to evaluate the conformity of European countries' leave regulations to four ideal typical divisions of labour. FSITA has its origin in qualitative comparative analysis and fuzzy set social sciences as articulated most extensively by Ragin $(2000,2008)$ and represents a relatively new method of investigation for assessing diversity across a limited number of cases. To date, it has been employed in a few studies of welfare state change (Kvist 1999, 2007a; Hudson and Kuhner, 2009; Vis, 2007) and to the comparison of national childcare provisions (Szelewa and Polakowski, 2008). At the core of this method is the idea that cases can be viewed as configurations of multiple dimensions, so that differences in one of these dimensions may amount to a difference in kind and not only in degree. At the same time, since the fuzzy set approach allows for partial membership of a case in a given configuration, it also allows the evaluation of cases' relative correspondance to theoretically specified ideal types (Kvist, 1999).

There are a number of reasons why this method is appropriate for the problem under investigation. The complexity of leave policies derives from the fact that many aspects must be considered simultaneously (payments, durations, transferability, etc.), whilst each of them may at the same time assume a different meaning according to the other aspects that comprise the overall policy design. FSITA attempts to overcome this limitation by viewing those different aspects not as independent, separable variables but as elements of configurations which have meaning only in relation to the whole that they form (Kvist, 2007b). Second, the fuzzy set approach does not allow for compensation effects mask the real extent of diversity (Hudson and Kuhner, 2009). If a country offers only low flat-rate payments, it cannot compensate for this by offering extremely long durations. Each aspect within a configuration matters on its own in order to establish a country's membership in a given ideal typical model.

FSITA entails four basic steps. First, we need to identify theoretically relevant dimensions of the ideal types leading to the construction of a useful property space, i.e. all logically possible combination of the selected dimensions. The number of possible ideal typical locations is $2 \mathrm{k}$, with $\mathrm{K}$ equal to the number of aspects considered. Not all these combinations need to be theoretically relevant or empirically valid (Vis, 2007; Kvist, 2007b). 
Secondly, each of these aspects needs to be defined as a set in which cases can have a degree of membership. Once the dimensions have been translated into empirical indicators (operationalization), we need to establish qualitative anchors in order to transform empirical values into 0 to1 fuzzy scores (calibration). Accordingly, the researcher defines three breakpoints for each dimension: full membership (1), no membership (0) and crossover point (.50), which represents the point where a case begins to move from being more out to being more in the set ${ }^{3}$. This operation primarily rests on theoretical and substantive knowledge of the phenomena investigated. Therefore, FSITA differs from traditional quantitative approaches in that it forces the researcher to reconsider the data in relation to external conceptual standards, and is not content with using averages and standard deviations that depend on the characteristics of the cases investigated. After all, averages are sample specific, ideal types are not (Kvist, 1999: 243).

In FSITA the ways in which fuzzy sets combine are equally important as the scores for each fuzzy set. The next step consists thus in the calculation of each case's membership score in the theoretically relevant configurations. Two principles of fuzzy theory are particularly useful. The minimum principle (or set intersection) according to which the conformity of a case to an ideal typical location is given by the minimum value score in the set involved. Accordingly, a case membership in an ideal type is defined by its weakest link since a case scoring low on dimension $A$ and high on $B$, can hardly be conceived as belonging to the ideal type defined by the combination $A^{*} B$ (where ${ }^{*}=$ and). The second principle is logical negation and follows from the logic of partial membership. To the extent to which a case is not fully in a certain set, it is partly in the set defined by its absence. For instance, if a case has a membership of .60 on set $A$, its corresponding score in the set $\sim A$ (where $\sim=$ not) will be .40 .

The last step consists of the evaluation of each case's membership in the different ideal types in order to identify the configuration with the highest score. Each case can have membership (fuzzy score $>.50$ and $\leq 1$ ) only in one configuration. However, since ideal types are rarely encountered in reality, cases will normally have only partial membership in a given configuration $(<1)$. In this way, the fuzzy set approach allows us to study differences across cases both in terms of configuration and degrees of membership. At the same time, by examining cases' scores in the remaining configurations (non-membership), we might be able to detect traces of those other models which may be present in national policies.

\section{Defining parental leave ideal types}

Parental leave policies essentially provide two kinds of rights: 1) the right to job-protected time off from work to care for a child (T) and 2) the right to receive monetary compensation during these periods (V). The combined effect of these two elements has been extensively investigated in analyses of leave generosity (Gornick et al., 1997; Gornick and Meyers, 2003; Ray et al., 2010; Moss and O'Brien, 2006; Moss and Wall, 2007). In this paper, they will be considered separately to take into account the fact that countries may differ in the extent to which they consider families responsible for childcare and the extent to which care activities are valued. Moreover, in order to assess the impact of leave regulations on gender equality, we also need to incorporate: 3) the distribution of rights between parents (concentration of care) (G), and 4) the presence of incentives for fathers to use leave (transformation of gender roles) (F) (see table 3). 
The combination of these four dimensions yields sixteen possible configurations, of which six correspond to the four ideal types described in the third section ${ }^{4}$. Both the universal breadwinner and the universal caregiver models are described by more than one combination. Given the primacy of the workplace characterizing the UB, leave entitlements tend to be very short and unvalued (unsupported UB). However, since the brevity of these periods reduces work disincentives, a second combination offering higher payments is also possible (supported UB). Conversely, the UC equally recognizes and values the right of both parents to care time and aims to transform traditional gender roles. Ideally, the right of parents to choose whether they will care for their children on their own or rely on other forms of care should extend over their life course, and anyway at least over the first years of the child's life (0-3) (full UC). Under such conditions, the problems related to employers' statistical discrimination against women would also be mitigated since men and women would engage in leave equally. A second variant is however also possible, in which parents' engagement in employment is given more prominence and the period granted is considerably shorter (around 1 year) (limited UC).

[table 2]

\section{Dimensions of comparison, operationalization and calibration of the fuzzy-sets}

This section discusses in more detail the four dimensions defining the ideal types, their operationalization and the calibration of the sets (table 3 and 4)

[table 3]

Reliance on family care. Leave policies recognize families' right/duty to provide childcare by offering parents the right to job-protected time off from work. The duration of these periods varies dramatically across Europe with some countries offering only a couple of weeks of maternity protection and others as much as six years of leave (figure 1). These differences directly reflect differences in the importance attributed to familial care. To measure this dimension, we have developed an index of total parental leave time which considers the overall number of weeks granted to families by maternity, paternity and parental leave regulations ${ }^{5}$. The longer this period, the higher the state's reliance on families as principal childcare providers. This variable can also be considered as an indicator of the extent of -supported or unsupported-familialism (Leitner, 2003). When more than one arrangement is possible, we followed the rule of the least generous option and considered the shortest period available to parents. Calibration. The minimum threshold is set at 14 weeks, which represents a generally recognized minimum standard -ILO Maternity Convention (2000), EU Maternity Directive (1992). The possibility for at least one of the parents to remain home until the child's third birthday (156 weeks) conversely implies a high reliance on the care provided by family members (fully in). The crossover point $(0.50)$ should reflect both the point where the parents' and children's rights to care time begins to be recognized (Knijn and Kremer, 1997) and considerations about the negative effects of prolonged absence from work on individuals' employment perspectives. There is no simple formula to determine this optimal length of leave since the impact will be influenced to a large extent by socio-cultural norms and other institutions, including the availability of childcare alternatives and the characteristics of the labour market 
(Gornick and Meyers, 2008). However, given that a period of around one year is considered to have little negative consequences on individuals' employment perspectives (Albrecht et al., 1999; Evertsson and Duvander, 2011; Galtry and Callister, 2005) and child well-being (Kamerman: 2006; UNICEF, 2008; Waldfogel, 2006), the crossover point is set at 78 weeks per family6.

[figure 1]

Monetary value of family care. How much of the overall time entitlement is valued time? Families' leave use depends crucially on whether these periods are paid or not and on the level of benefits offered. High compensations also send important signals that parental care is socially valued, which is an important precondition for gender equality (Lammi-Taskula, 2006). In this view, there are stark differences in the level of financial support offered by national regulations. Shorter leaves are generally, but not always, better paid than longer ones. To consider this, we measured the value attributed to family care as the ratio between the full-time equivalent (FTE) entitlement and the total parental leave time in number of weeks.

The first step was to convert families' aggregate leave entitlements in full-time equivalents. FTE leave is calculated as the duration of paid weeks of leave multiplied by the wage replacement rate, and indicates the effective number of weeks if those were paid at full-wage replacement rate $(100 \%)$. For those countries that offer only flat-rate benefits, we calculated the replacement rate using the net income of an Average Production Worker (Eurostat, 2008). In a few countries (Austria, Czech Republic, Estonia, France, Latvia), parental leave is not formally paid but there are childcare allowances available to parents during these periods. Since these benefits represent a way to finance absence from work, we consider them among leave payments. In three of these countries (CZ, LT, FR), parental leave is an individual right but only one of the parents can receive benefits (family entitlement). Since parents are not individually entitled to a certain amount of time and money, we coded these periods as shared entitlements. The Czech Republic, for instance, grants parents an individual leave right until the child's third birthday paid at a flat rate benefit which equals $37.9 \%$ of average wages. Accordingly, we coded 312 weeks at a replacement rate of $18.95 \%$ as shared entitlement (i.e. 59.1 FTE weeks).

The ratio between the overall family FTE entitlement and the total number of weeks of leave indicates the extent to which leave time is valued time. This index can vary between zero and one. It equals zero when there is no monetary compensation and 1 if all the time is compensated at $100 \%$ of previous wages. For instance, an index of .50 indicates that $50 \%$ of leave time is unvalued, or in other words, that working-time is worth twice as much as care time. Calibration. The first threshold (fully out) is set at 30 per cent of previous wages since we can easily assert that countries that value leave 30 per cent or less than working-hours do not actually value family care. The second threshold (fully in) is set at a replacement rate of $90 \%$ since care and work are essentially considered equally valuable. The crossover point (.50) is set at $60 \%$ representing the point where leave time begins to move from being mostly unvalued to being mostly valued.

[figure 2] 
Gender concentration of leave. Whereas the previous two dimensions considered aggregate supports available to families, this dimension looks at the distribution of rights within the family and the extent to which it is balanced/unbalanced. Accordingly, we developed an index of concentration of leave that measures the extent to which mothers and fathers enjoy equal rights to leave time and benefits.

The first step was to recode all entitlements according to the subject to which they are exclusively available: mother, father or both parents. For instance, if parents are each granted an individual right to 3 months of parental leave, we coded 3 months as mother's entitlement and 3 months as father's entitlement. Father's quotas and bonus-periods (Finland, Germany, Portugal) provided on the basis that the father takes some of the shared leave, are also considered fathers' entitlements since they would also be lost if not used. In a few countries (Bulgaria, Portugal, Spain, Czech Republic, Poland), a certain period of maternity leave is also transferable to the father. However, given the prevalence of cultural norms that place primary responsibility with mothers, this is unlikely to occur in the absence of further incentives (Ray et al., 2010; Verloo, 2010)7 ${ }^{7}$. Since only Portugal offers such incentives (i.e. 30 fully paid days), we proceeded in this case to recode the transferable part of maternity leave under shared leave.

We defined our index of leave concentration as the ratio between the difference in entitlements to paid leave between mothers and fathers and their joint entitlement:

Formula: 1-(FTE mother's leave-FTE father's leave)/(FTE mother's leave +FTE father's leave)

This index equals zero if only the mother is entitled to leave (maximum concentration) and 1 when parents enjoy equal rights (equidistribution). For instance, a value of .50 indicates that the mother enjoys 50\% more entitlements than the father. Values greater than 1 indicate that fathers have more individual rights than mothers (Norway, Portugal, Sweden). Theoretically, this index would equal 2 if the father would be the sole person entitled to leave. Calibration: The minimum crossover point is set at 85 since biological differences between the sexes justify a mother's right to some additional time to recover from childbearing (Robeyns, 2007). This is normally acknowledged in leave policies through (variable) periods of mandatory postnatal leave. The maximum cut-off point is set at zero corresponding to the situation of no entitlement for fathers. The point of maximum ambiguity is set at .60 (mothers have 40\% more rights than fathers) corresponding to the situation in which fathers' entitlements begins to represent a substantial part of the overall family entitlement.

[figure 3]

Incentives for fathers to use leave. To which extent do leave policies consolidate the norm that fathers should take time off from work to care for their children? The right to a few well-paid days off from work hardly advances new norms about fatherhood. Likewise, equal rights that are based on similarly poor entitlements (e.g. the right to long periods of unpaid leave) are unlikely to promote a higher use of leave among fathers. In this view, it is not sufficient to provide equal rights to challenge the traditional division of care, but fathers should be offered real incentives to actually make use of them.

There is a strong consensus in the literature that fathers' take up of leave is strongly influenced by the co-presence of two conditions: 1) some reserved period, and 2) benefits which 
replace a substantial amount of normal wages (Bruning and Plantenga, 1999; Gornick and Meyers, 2003; Moss, 2008; Moss and O’Brien, 2006; Rostgaard, 2002). Several countries have introduced individual, non-transferable rights for fathers. These include paternity leaves, fathers' quotas and the right to extra time if the father shares some of the leave (Germany, Finland, Italy, Portugal). Since fathers are still likely to earn more than mothers, and given that paid work represents the norm for men, the likelihood that these rights are used crucially depends on the fact that all these periods are generously remunerated. Empirical research shows that fathers normally use all those well-paid periods that are reserved to them, while their participation in shared leaves remains limited, which accounts for the persistence of considerable gender gaps in the average leave duration (Bruning and Plantenga, 1999). Although modest in duration, fathers' quotas produce normative guidelines for the behaviour of fathers. If the father does not use them, both parents and child will be punished by losing these periods of paid leave. At the same time, these rights can help fathers to circumvent workplace constraints by obligating employers to accommodate their leavetaking requests (Brandth and Kvande, 2001; Leira, 2002).

Flexibility in uptake is another feature of parental leave that can potentially raise fathers' leave use by contrasting fears of being disconnected from the workplace and negative attitudes of employers (Kremer, 2007; Rostgaard, 2002). However, flexibility in the form of part-time or piecemeal leaves remains a gender-neutral measure not specifically targeted to fathers, and as such it lacks the obligating intention characteristic of fathers' quotas. Flexibility remains to a larger extent subject to negotiations between the mother, the father and the employer. Thus, for example, Brandth and Kvande (2001) in a study on Norwegian fathers' use of leave found that while the majority of fathers used the compulsory period, the uptake of the flexible part was hindered by fears about potential negative impacts on their careers.

The last aspect considered concerns the promotion of a father's role as primary carer with full responsibility for the child during his leave. Unlike paternity leave, which is normally taken soon after childbirth when the mother is also at home with the baby, national regulations differ in the extent to which they simultaneously allow parents to take parental leave. In practice, it is common for the mother to take some holidays or sabbatical leave in order to remain at home during the father's parental leave (Lammi-Taskula, 2006). Nevertheless, non-simultaneous entitlements represent a step forward towards the norm that fathers can and should be carers on their own.

We developed an index of fatherhood opportunity to measure differences across countries in the extent to which fathers are offered any of these incentives (figure 4). Our index has three components:

1. Reserved or shared time paid at least $67 \%$ of normal wages (maximum 12 points) 8 . This is the most important element of our index, in accordance with previous research that has shown the importance of the combination of non-transferable rights and generous economic compensation for fathers' use of leave.

2. Flexibility of leave in terms of part-time (1 point) or piecemeal leave (1 point), or both (3 points).

3. Non-simultaneity of leave entitlements (1 point)

Table 4 summarizes the allocation of points to these different elements.

Calibration: The maximum cut-off point (fully in) is set at 16 points, corresponding to the copresence of all conditions. The minimum cut-off point is set at zero corresponding to the absence of all these characteristics. The point of maximum ambiguity is set at 9 points which corresponds to 
the situations in which either fathers enjoy an exclusive entitlement to more than one well-paid month but none of the other incentives, or all other incentives and no considerable well-paid period of leave for fathers are present.

[table 4 and figure 4]

[table 5]

\section{Results}

Table 6 shows countries' fuzzy membership scores in the six ideal typical models introduced above. Each of the countries analyzed has membership in one of the configurations, with the exception of Luxembourg and Germany ${ }^{9}$. There are differences across cases in levels of membership, and some countries only weakly conform to ideal types (e.g. United Kingdom). This is rather unsurprising since ideal types are best defined by their extension of zero and scores of around 0.50 are rather common in FSITA (Hudson and Kuhner, 2009; Szelewa and Polakowski, 2008; Vis, 2007). In this sense, these cases show that tensions between different aims and policy inconsistencies are rather common in reality (Leitner, 2003), and should be reflected in this analysis.

[table 6]

The full universal caregiver model does not yet empirically exist. None of the countries considered conforms to this ideal type. Even the Nordic countries, normally regarded as the paragons of gender equality, show only traces of this model because of leave durations that are too short to achieve membership in this configuration. Sweden, offering 16 months of leave, is the country that comes closest to it $(.41)^{10}$.

Leave policies in Finland, Iceland, and Sweden configure only a limited caregiver model (LUC), which is characterized by generous compensation, similar rights for both parents, reserved time and other incentives for fathers, but durations that reach just around 1 year (and as low as 39 weeks in Iceland). Even though gender equality represents an important goal in these countries, it has to compete with another important element of their welfare states, their strong commitment to full employment (Ciccia, 2010; Huo et al., 2008). The imperative that individuals' detachment from the labour market should be as brief as possible accounts for the relative brevity of periods granted to parents to be full-time carers for their children. However, in the Nordic countries part-time leaves make it also possible to spread entitlements over longer periods at a lower (but still high) level of benefits. In Norway, for instance, parents can choose between 44 weeks at $100 \%$ or 56 weeks at 80\%. In Finland and Norway, additional periods of childcare leave are also available to parents until the child's third birthday. However, this time is only paid at a lower flat-rate level. These allowances thus contravene the goals of the universal caregiver model since men have virtually no incentives to take these leaves, while mothers are encouraged to exit the labour market for up to three years (Morgan, 2008). Overall, these countries offer parents strong incentives to return to work within a 
year from childbirth; a period normally considered to have little negative impact on employment perspectives and wages (Albrecht et al., 1999).

In Scandinavian countries, long leaves are regarded as not only disadvantageous to maternal employment but also to children's development. In these countries, societal norms position children's well-being as a public responsibility, and childcare services as an equal or more acceptable alternative to full-time parental care. Childcare facilities are conceived as a fundamental investment in education intended to provide children with equal opportunities regardless of their family background. This strategy represents a crucial element of what has become known as the social investment state (Esping-Andersen et al., 2002). At the same time, the right of children to parental care during their first year is a well-established norm since this time is considered essential for the early year development (Rostgaard, 2002). Therefore, periods of leave of around one year seem to both accommodate Nordic countries' 'early-return-to-work' ethic and their ambition to offer children equal life chances.

While previous research has generally acknowledged Scandinavian states' 'passion for equality', Portugal has hardly been depicted as a high performer in this area. Still, Portuguese leave policy also belongs to the LUC configuration because of the major changes introduced by the last reform in 2009. Maternity leave was replaced with periods of initial (120-150 days), father only (20 fully-paid days) and additional leave (3 months individual entitlement). Parents are also offered substantial incentives to share leave (1 bonus month) and to choose part-time over full-time leave (12 part-time or 3 full-time months). Moreover, the reform enhanced flexibility by giving parents a number of options with regard to duration and level of benefits. Parental leave in Portugal appears thus to have taken a decisive Scandinavian turn, even though some of these periods remain poorly compensated, which accounts for Portugal's low score in this configuration (.53).

Our analysis also shows that despite claims about the demise of the male breadwinner ideal (Crompton, 1999; Lewis, 2001), this remains well-entrenched in European welfare states. One-third of the countries analyzed (Austria, Czech Republic, Estonia, France, Hungary, Latvia, Poland, Slovakia, Spain, United Kingdom) have policies based on a traditional division of gender roles. In these countries, regulations typically grant long leaves (3 or more years), but these periods are unpaid or paid only at low, flat-rate levels. Other features of leave policies are the prevalence of family entitlements, limited flexibility and only a couple of days of paternity leave for fathers. There are differences across these countries with regard to their degree of membership in this model. For instance, in the United Kingdom leave policy appears divided between the contrasting aims of supporting the traditional family and a general non-interventionist family policy model (Daly, 2010). Indeed, this country achieves almost the same score in the MB (.52) and UUB (.48) configurations. Nevertheless, the length of maternity protection (1 year) as well as the overall leave duration (more than 18 months) indicate that the care of small children remains within the home and that mothers are still expected to be the primary carers.

In contrast, the most recent parental leave reform (2007) marked the departure of Germany from the MB ideal; this is also demonstrated by the fact that Germany does not achieve membership in this configuration. This new legislation has fundamentally reshaped parental leave by introducing for the first time an earning-related benefit (Elterngeld), a sharing-bonus for fathers ( 2 months) and by shortening the paid period from 24 to 12 months. While several authors (Erler, 2009; Spiess and Wrohlich, 2008) have welcomed these changes as a Nordic turn in German leave policy, there are still elements in place that support the MB ideal (Leitner, 2010). Thus, for instance, even though the sharing-bonus can be interpreted as a special support to father care, it lacks the force of obligatory daddy quotas, and implies that parental leave is still expected to be taken mainly by the mother 
(Leira, 1992). This combines with a relatively moderate level of compensation (67\%) and benefit ceiling (€1800). Moreover, although the benefit span has been shortened, the duration of parental leave may still last until the child's third birthday. In this sense, recent changes have, for the moment, been more effective in eroding the male breadwinner ideal than in establishing a clearly identifiable new model.

The caregiver parity model comprises three Central Eastern European countries: Bulgaria, Lithuania and Romania. These countries' policies appear similar to those of the MB but here maternal care is compensated by generous benefits. Several authors (Hantrais, 2004; Saxonberg and Szelewa, 2007) have documented a general trend in post-communist countries during the transition period from dual-earner families and extensive childcare services towards the 'refamilialization' of mothers and extended paternal leave provisions. This change, however, does not represent a completely new development since communist governments continued to support traditional gender roles in spite of high levels of female labour market participation. Thus, these countries already combined high rates of female employment and childcare expenditures with long periods of maternity leave. After the transition, parental leave regulations supplanted these extended maternity leaves, and even though fathers' are for the first time allowed to share these entitlements, they are not actually expected to use them. For instance, parental leave in Bulgaria is still fundamentally a mother's right that is transferable to the father (or grandparents) only upon her consent. In Romania, only one parent can use the whole leave entitlement, creating considerable disincentives to use by fathers. Still, in contrast to other ex-communist countries that have reduced benefits' generosity because of budget constraints, these countries still support a more generous form of (re)familialism.

The unsupported universal breadwinner model represents the second most common configuration among European countries. Seven countries (Belgium, Cyprus, Greece, Ireland, Italy, Malta, Netherlands), and the European Union itself have regulations that resemble this ideal type. In these countries, leave policies provide limited support and those few provisions are fundamentally intended to the protection of maternal and children's health. Thus, maternity leave (14-26 weeks) accounts for a large share of the overall entitlement (around 1 year) and is generally highly paid. Parents may also enjoy individual rights to short periods of parental leave but these are normally unpaid, offering few incentives for fathers to use them. There is some degree of flexibility in terms of part-time and piecemeal leave since parents 'keeping in touch' with the workplace is generally considered positively. Among the countries in this configuration, Italy, Ireland, and the Netherlands achieve similar scores in the UUB and MB configurations, showing the presence of tensions within the policy design between the contrasting aims of promoting maternal employment and securing familial care. It may appear surprising to find also countries with very low female employment rates (Italy, Greece, Malta) in this configuration. However, these countries' policies are as residual and formally neutral as the others'. Their 'implicit familialism' resembles a laissez-faire model in the sense that the state does not directly intervene in family relations and seeks to exercise no influence on families at all (Leitner, 2003). Accordingly, since women are hardly employed, the state does not need to offer protections to ensure familial care. Both the liberal and unsupported familialistic models thus adopt non-interventionist leave designs, the former not to alter the normal functioning of market forces and the latter not to interfere in family life and responsibilities. Although the focus of this analysis is on formal regulations, it is important to stress that similar policies can have different meanings and effects across contexts.

In the supported universal breadwinner model (Denmark, Slovenia, Switzerland), leave regulations appear similar to those typical of the PUB model, but parents (mothers) are offered 
higher financial compensations since the brevity of entitlements reduces the risk of work disincentives. These provisions are narrowly intended to secure women equal rights to participate in the labour market, and indeed these countries have some of the highest female employment rates in Europe. Among the Nordic countries, only Denmark belongs in this group. In contrast to other countries, the extension of leave rights occurred here when women's integration in employment was already well underway, and it was aimed at facilitating mothers to retain their labour market position rather than at encouraging fathers to be more active in childcare (Rostgaard, 2002). The Danish gender equality project thus appears to be relatively 'narrow', with childcare policies largely inspired by the principle of gender neutrality and negotiations over care time confined to a private matter of choice for families (Borchorst, 2006). Accordingly, Denmark has for decades been at the forefront of expanding childcare facilities for children under 1 year, but fathers enjoy few individual leave rights. Indeed, this is now the only Scandinavian country without a father's quota after its abolishment in 2002.

\section{Conclusions}

This article uses fuzzy-set ideal type analysis to assess the conformity of European countries' leave policies to four ideal typical divisions of labour -male breadwinner, caregiver parity, universal breadwinner and universal caregiver (Fraser, 1994). In contrast to the majority of previous studies, the focus of this analysis is on the extent to which leave regulations promote the transformation of traditional gender roles in paid and unpaid work. Moreover, the use of ideal types contributes to systematizing and giving theoretical meaning to parental leave policy variation in Europe by highlighting which conceptions of gender (in)equality are implied in different policy configurations. Accordingly, while some parental leave arrangements encourage women to stay at home (MB, CGP), others narrow gender equality to the promotion of maternal employment (UB), and others still widen it to include supports for both men's and women's equal engagement in work and care (UC).

The results of this analysis show that European leave policies cluster into five models that only partly coincide with countries' geographical proximity. Thus, for instance, the Nordic countries have followed different approaches to leave provisions, with Sweden more strongly emphasizing fathers' engagement in childcare and Denmark more narrowly focusing on labour market outcomes. Likewise, the presence of incentives for fathers' to engage in childcare distinguishes Portugal from other Southern European states. Nevertheless, the universal caregiver model does not yet exist anywhere in Europe. Even the Nordic countries, generally held up as role models for gender equality policies, only limited resemble the universal caregiver ideal because of the presence of strong incentives to return to work within a year of childbirth. Conversely, the presence of a large number of countries in the male breadwinner configuration shows that, in spite of massive changes in both policy rhetoric and women's preferences and behaviors, this model continues to provide the normative reference point for parental leave policies in a large number of European states. Onethird of the countries analyzed present policies based on a traditional division of gender roles with long periods of poorly compensated leave, while three of the Central and Eastern European states (Bulgaria, Lithuania, Romania) also support the traditional family model but provide higher rewards for maternal care.

The universal breadwinner ideal is the second most common configuration among European countries, testifying to the growing emphasis on female employment growth. This model only acknowledges gender equality goals in relation to the labour market and does not question persistent gender unbalances in the division of unpaid work. Moreover, since both parents are 
supposed to be in employment, parents' right to care time, as well as the existence of limits to the commodification of care via formal childcare are only limitedly recognized. Accordingly, in a considerable number of countries and the EU, leave policies are residual and have noninterventionist designs (unsupported UB). Denmark, Slovenia and Switzerland offer more generous leave facilities, but these are also limitedly intented to securing women's equal rights to participate in paid employment (supported UB). Finally, the presence of the EU within this configuration shows that European regulations might have been more successful in laying down minimum standard than in fostering convergence among member states or in taking the lead in questioning the gender division of unpaid labour. Given the focus of this article on parental leave, more research will have to be done in order to incorporate other crucial care policies (e.g. childcare services, working-time regulations) with regard to the extent of their structural inequality. 
Tables \& Figures

Table 1: Parental leave ideal types

\begin{tabular}{lcccccc}
\hline Ideal types & \multicolumn{2}{c}{ Women } & \multicolumn{2}{c}{ Men } & $\begin{array}{c}\text { Concentration of } \\
\text { rights }\end{array}$ & $\begin{array}{c}\text { Fathers' } \\
\text { incentives }\end{array}$ \\
\hline Male breadwinner & Time & Money & Time & Money & - & + \\
Caregiver parity & + & - & - & - & + & - \\
Universal breadwinner & - & $+/-$ & - & - & + & - \\
Universal caregiver & + & + & + & + & - & + \\
\hline
\end{tabular}

Table 2: Property space of parental leave ideal types*

\begin{tabular}{lcccc}
\hline Models & $\begin{array}{c}\text { Time to care } \\
(\mathrm{T})\end{array}$ & $\begin{array}{c}\text { Value of care } \\
(\mathrm{V})\end{array}$ & $\begin{array}{c}\text { Concentration } \\
\text { of care work } \\
(\mathrm{G})\end{array}$ & $\begin{array}{c}\text { Father's } \\
\text { incentives } \\
(\mathrm{F})\end{array}$ \\
\hline Male breadwinner & $\mathrm{T}$ & $\sim \mathrm{V}$ & $\mathrm{G}$ & $\sim \mathrm{F}$ \\
$\begin{array}{l}\text { Caregiver parity } \\
\begin{array}{l}\text { Unsupported universal } \\
\text { breadwinner }\end{array}\end{array}$ & $\mathrm{T}$ & $\mathrm{V}$ & $\mathrm{G}$ & $\sim \mathrm{F}$ \\
$\begin{array}{l}\text { Supported universal } \\
\text { breadwinner }\end{array}$ & $\sim \mathrm{T}$ & $\sim \mathrm{V}$ & $\mathrm{G}$ & $\sim \mathrm{F}$ \\
Limited universal caregiver & $\sim \mathrm{T}$ & $\mathrm{V}$ & $\mathrm{G}$ & $\sim \mathrm{F}$ \\
Full universal caregiver & $\sim \mathrm{T}$ & $\mathrm{V}$ & $\sim \mathrm{G}$ & $\mathrm{F}$ \\
\hline U & $\mathrm{T}$ & $\mathrm{V}$ & $\sim \mathrm{G}$ & $\mathrm{F}$
\end{tabular}

*Upper-case letters indicate membership in a set, while letters preceded by the symbol $\sim$ denote the absence or negation of the set.

\section{Table 3: Dimensions and measures}

\begin{tabular}{l|l}
\hline \multicolumn{1}{c|}{ Dimensions } & \multicolumn{1}{c}{ Measures } \\
\hline Reliance on family care & Total parental leave time \\
Monetary value of family care & FTE leave*/total leave time ratio \\
Concentration of care work & Index of leave concentration \\
Transformation of gender roles & Fatherhood opportunity index \\
\hline
\end{tabular}

*Full-time equivalents (FTE) are calculated as the duration of paid weeks of leave multiplied by the wage replacement rate. 
Figure 1: Total parental leave time (number of weeks) (2010)

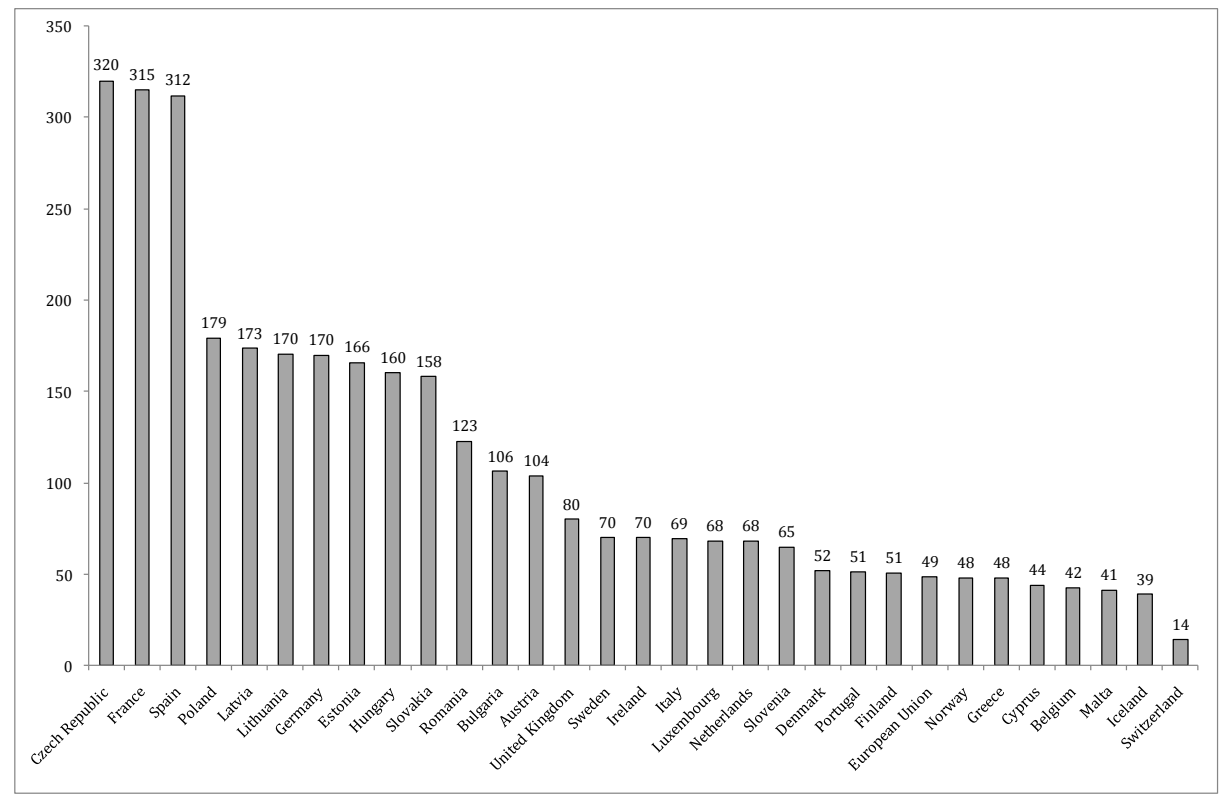

Figure 2: Full-time equivalent (FTE) leave /total leave time ratio (2010)

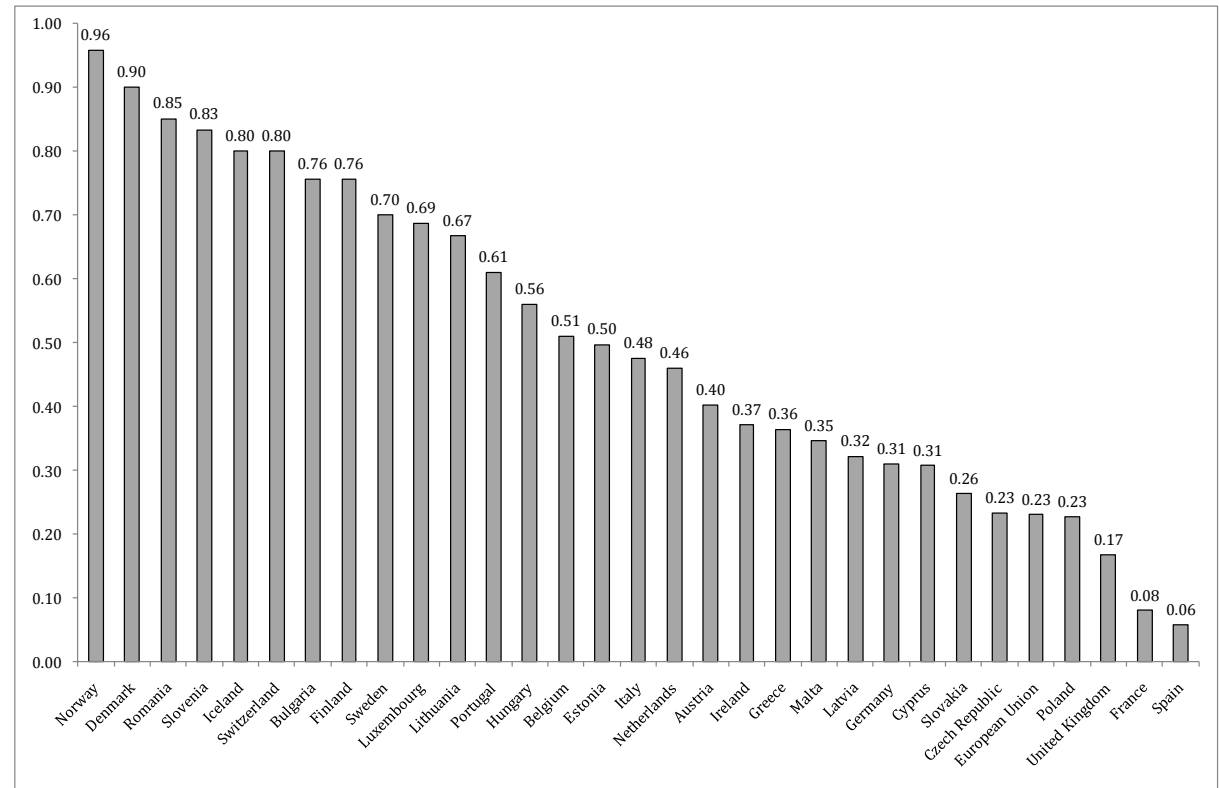


Figure 3: Index of concentration of FTE leave (2010)

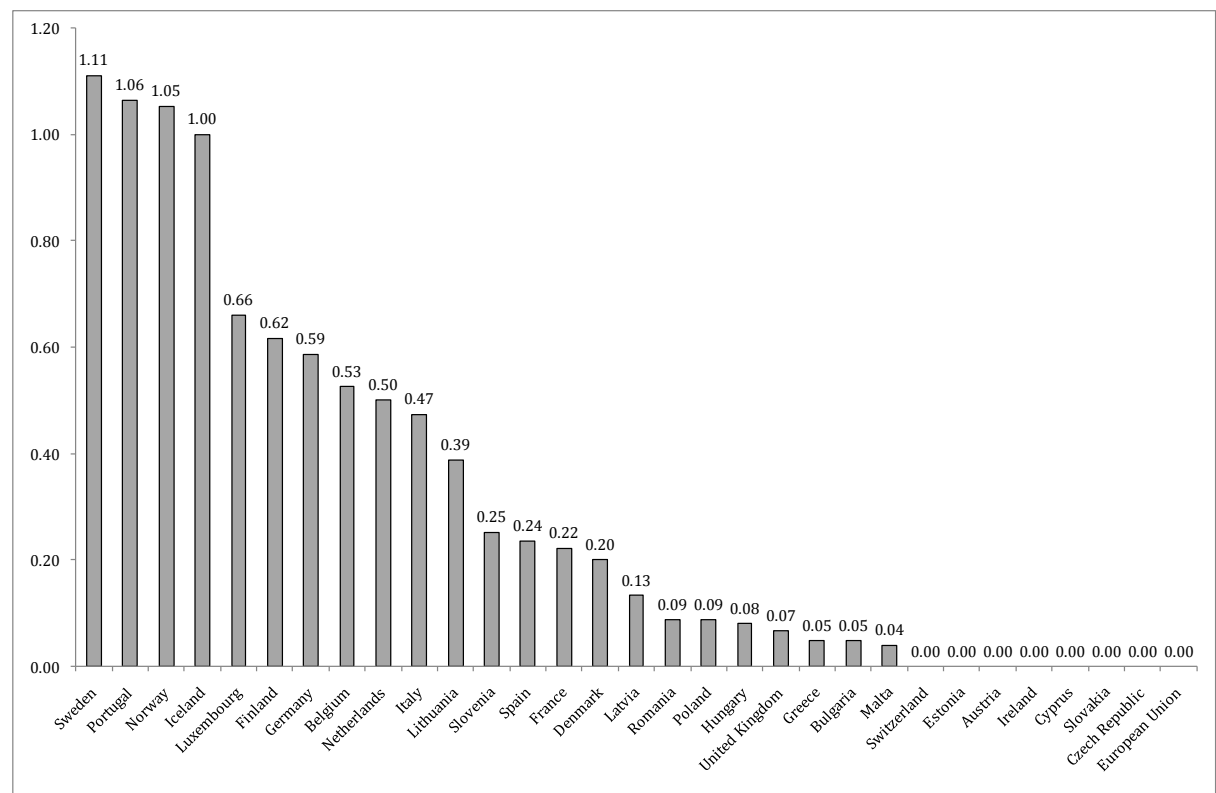

Table 4 Fathers' opportunity index: allocation of points

\begin{tabular}{lc}
\hline Characteristics & Score \\
\hline Time paid at least 67\% of wages & max. 12 \\
\hline Reserved period of more than 1 week and up to 1 month & 2 \\
Reserved period of more than 1 month & 9 \\
Shared time & 3 \\
Flexibility & max. 3 \\
Only part-time leave & 1 \\
Only piecemeal leave & 1 \\
Both part-time and piecemeal leave & 3 \\
Primary carer & max. 1 \\
\hline Non-simultaneity of parental leave & 1 \\
\hline
\end{tabular}


Figure 4: Fatherhood opportunity index (2010)

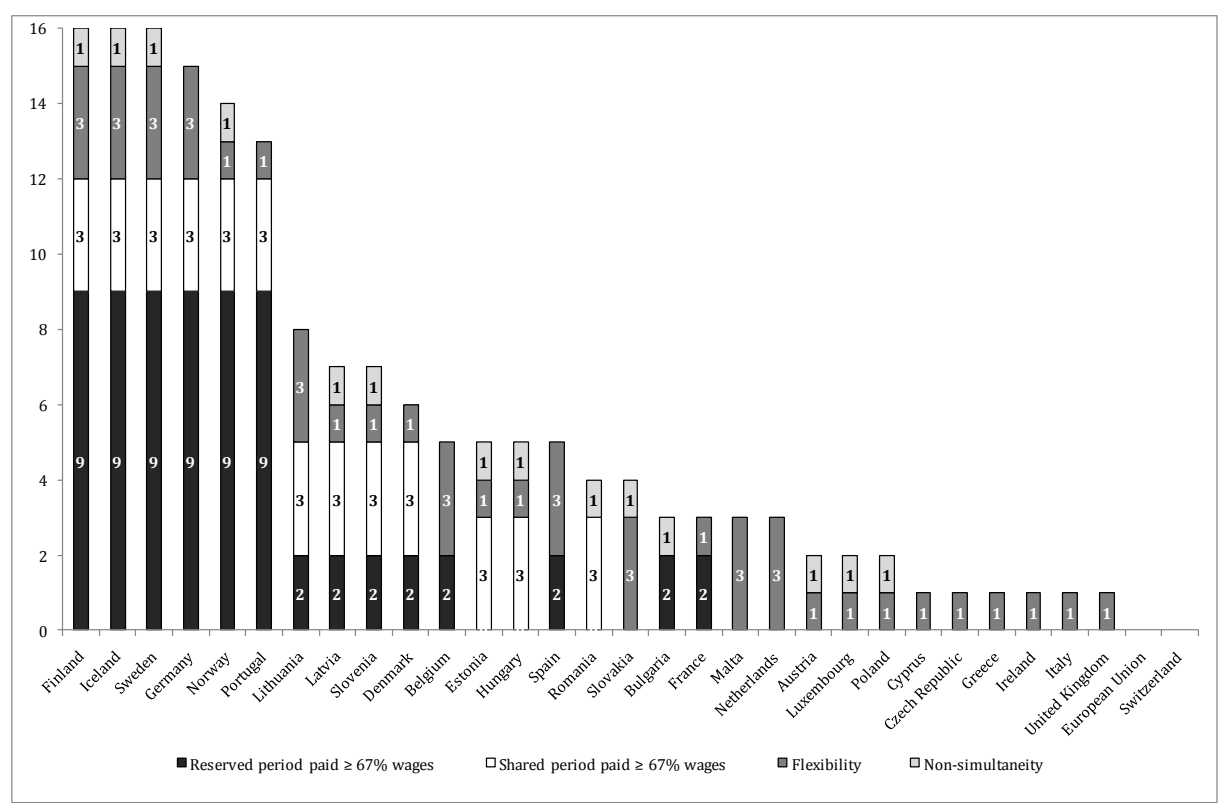

Table 5: Specification of empirical indicators and translation of data to fuzzy scores range

\begin{tabular}{|c|c|c|c|}
\hline & Fully in & $\begin{array}{c}\text { Neither more in } \\
\text { nor out }\end{array}$ & Fully out \\
\hline Empirical indicator & 1.00 & 0.50 & 0.00 \\
\hline $\begin{array}{l}\text { Reliance on family care measured as the overall } \\
\text { number of weeks per family of job-protected absence } \\
\text { from work granted by leave regulations }\end{array}$ & 156 & 78 & 14 \\
\hline $\begin{array}{l}\text { Monetary value of care measured as the ratio between } \\
\text { FTE leave entitlement and the total leave time granted } \\
\text { per family }\end{array}$ & 0.90 & 0.60 & 0.40 \\
\hline $\begin{array}{l}\text { Concentration of leave rights measured as the } \\
\text { difference to } 1 \text { of the ratio between the difference in } \\
\text { entitlements between parents and their joint } \\
\text { entitlement }\end{array}$ & 0.00 & 0.60 & 0.85 \\
\hline $\begin{array}{l}\text { Transformation of gender roles measured by the } \\
\text { presence of incentives for fathers' leave use }\end{array}$ & 16 & 9 & 0 \\
\hline
\end{tabular}


Table 6: Fuzzy membership scores of parental leave policies in ideal types*

\begin{tabular}{|c|c|c|c|c|c|c|}
\hline Country & $\begin{array}{c}\text { Full universal } \\
\text { caregiver } \\
\text { (FUC) }\end{array}$ & $\begin{array}{c}\text { Limited } \\
\text { universal } \\
\text { caregiver LUC }\end{array}$ & $\begin{array}{c}\text { Unsupported } \\
\text { universal } \\
\text { breadwinner } \\
\text { (UUB) }\end{array}$ & $\begin{array}{c}\text { Supported } \\
\text { universal } \\
\text { breadwinner } \\
\text { (SUP) }\end{array}$ & $\begin{array}{c}\text { Male } \\
\text { breadwinner } \\
(M B)\end{array}$ & $\begin{array}{c}\text { Caregiver } \\
\text { Parity } \\
\text { (CGP) }\end{array}$ \\
\hline Austria & 0.05 & 0.05 & 0.27 & 0.05 & 0.73 & 0.05 \\
\hline Belgium & 0.16 & 0.21 & 0.60 & 0.21 & 0.16 & 0.16 \\
\hline Bulgaria & 0.06 & 0.06 & 0.17 & 0.25 & 0.17 & 0.75 \\
\hline Cyprus & 0.01 & 0.01 & 0.83 & 0.01 & 0.17 & 0.01 \\
\hline Czech Republic & 0.00 & 0.00 & 0.00 & 0.00 & 0.94 & 0.00 \\
\hline Denmark & 0.12 & 0.12 & 0.05 & 0.73 & 0.05 & 0.23 \\
\hline Estonia & 0.05 & 0.03 & 0.03 & 0.03 & 0.79 & 0.18 \\
\hline European Union & 0.00 & 0.00 & 0.80 & 0.00 & 0.20 & 0.00 \\
\hline Finland & 0.22 & 0.56 & 0.05 & 0.05 & 0.05 & 0.05 \\
\hline France & 0.00 & 0.00 & 0.00 & 0.00 & 0.87 & 0.00 \\
\hline Germany & 0.01 & 0.01 & 0.05 & 0.01 & 0.03 & 0.01 \\
\hline Greece & 0.03 & 0.03 & 0.80 & 0.03 & 0.20 & 0.03 \\
\hline Hungary & 0.07 & 0.04 & 0.04 & 0.04 & 0.65 & 0.35 \\
\hline Iceland & 0.14 & 0.86 & 0.01 & 0.01 & 0.01 & 0.01 \\
\hline Ireland & 0.03 & 0.03 & 0.59 & 0.03 & 0.41 & 0.03 \\
\hline Italy & 0.06 & 0.06 & 0.60 & 0.14 & 0.40 & 0.14 \\
\hline Latvia & 0.01 & 0.01 & 0.02 & 0.01 & 0.66 & 0.01 \\
\hline Lithuania & 0.26 & 0.03 & 0.03 & 0.03 & 0.33 & 0.58 \\
\hline Luxembourg & 0.09 & 0.09 & 0.29 & 0.33 & 0.29 & 0.33 \\
\hline Malta & 0.02 & 0.02 & 0.85 & 0.02 & 0.15 & 0.02 \\
\hline Netherlands & 0.11 & 0.11 & 0.61 & 0.11 & 0.39 & 0.11 \\
\hline Norway & 0.20 & 0.80 & 0.00 & 0.00 & 0.00 & 0.00 \\
\hline Poland & 0.00 & 0.00 & 0.02 & 0.00 & 0.91 & 0.00 \\
\hline Portugal & 0.22 & 0.53 & 0.00 & 0.00 & 0.00 & 0.00 \\
\hline Romania & 0.07 & 0.07 & 0.08 & 0.15 & 0.08 & 0.84 \\
\hline Slovakia & 0.01 & 0.01 & 0.04 & 0.01 & 0.84 & 0.01 \\
\hline Slovenia & 0.15 & 0.15 & 0.09 & 0.65 & 0.09 & 0.35 \\
\hline Spain & 0.00 & 0.00 & 0.00 & 0.00 & 0.79 & 0.00 \\
\hline Sweden & 0.41 & 0.59 & 0.00 & 0.00 & 0.00 & 0.00 \\
\hline Switzerland & 0.05 & 0.05 & 0.12 & 0.88 & 0.05 & 0.05 \\
\hline United Kingdom & 0.00 & 0.00 & 0.48 & 0.00 & 0.52 & 0.00 \\
\hline
\end{tabular}

*Scores in bold designate membership in a given ideal type (fuzzy membership $>0.50$ ). Higher scores indicate a closer correspondence between a country's leave policy and the ideal type. 


\section{References}

Albrecht J.W., Edin P.A., Sundström M. and Vroman S.B. (1999) 'Career Interruptions and Subsequent Earnings: a Reexamination Using Swedish Data', Journal of Human Resources 34(2): 294-311.

Anttonen A. and Sipilä J. (1996) 'European Social Care Services: Is It Possible to Identify Models?'Journal of European Social Policy 6(2): 87-100.

Baker M. and Milligan K. (2008) 'How Does Job-Protected Maternity Leave Affect Mothers' Employment?', Journal of Labor Economics 26(4): 655-691.

Bettio F. and Plantenga J. (2004) 'Comparing Care Regimes in Europe', Feminist Economics 10(1): 85-113.

Borchorst A. (2006) 'The Public-Private Split Rearticulated: Abolishment of the Danish Daddy Leave, in A.L. Ellingsaeter and A. Leira (eds.) Politicising Parenthood in Scandinavia: Gender Relations in Welfare States, 101-120, Bristol: Policy Press..

Brandth B. and Kvande E. (2001) 'Flexible Work and Flexible Fathers', Work, Employment \& Society 15(2): 251-267.

Bruning G. and Plantenga J. (1999) 'Parental Leave and Equal Opportunities: Experiences in Eight European Countries', Journal of European Social Policy 9(3): 195-209.

Ciccia, R. (2010), 'I regimi di impiego europei tra selettività e regolamentazione', in M. Capparucci, Politiche del lavoro e politiche dei redditi. Modelli teorici e processi di riforma, Milano: Franco Angeli

Crompton R. (ed.) (1999) Restructuring Gender Relations and Employment: the Decline of the Male Breadwinner, Oxford: Oxford University Press.

Crompton R. (2006) Employment and the Family: The Reconfiguration of Work and Family Life in Contemporary Societies, Cambridge: Cambridge University Press.

Daly M. (2010) 'Shifts in Family Policy in the UK under New Labour', Journal of European Social Policy 20(5): 433-443.

Earles K. (2011) 'Swedish Family Policy -Continuity and Change in the Nordic Welfare State Model', Social Policy \& Administration 45(2): 180-193.

Ellingsaeter A.L. and Leira A. (eds.) (2006) Politicizing Parenthood in Scandinavia: Gender Relations in Welfare States, Bristol: Policy Press.

Erler D. (2009) 'Germany: Taking a Nordic Turn?', in S. Kamerman and P. Moss (eds.), The Politics of Parental Leave Policies: Children, Parenting, Gender and the Labour Market, Bristol: Policy Press.

Esping-Andersen G., Gallie D., Hemerijck A. and Myles J. (2002) Why We Need a New Welfare State, Oxford: Oxford University Press.

Eurostat (2008) Labour Market Earnings Database, Statistical Office of the European Communities. Available at:http://epp.eurostat.ec.europa.eu/portal/page/portal/labour_market/earnings. Accessed on 22.02.2011.

Evertsson M. and Duvander A.Z. (2011) 'Parental Leave -Possibility or Trap? Does Family Leave Length Effect Swedish Women's Labour Market Opportunities? ', European Sociological Review 7(4): 435-450. 
Ferrarini T. (2006) Families, States and Labour Markets: Institutions, Causes and Consequences of Family Policy in Post-War Welfare States, Cheltenham: Edward Elgar Publishing.

Fraser N. (1994) 'After the Family Wage: Gender Equity and the Welfare State', Political Theory 22(4): 591-618.

Galtry J. and Callister, P (2005) 'Assessing the Optimal Lengthof Parental Leave for Child and Parental Well-Being How Can Research Inform Policy?', Journal of Family Issues 26(2): 219246.

Gornick J.C. and Meyers M.K. (2003) Families that Work: Policies for Reconciling Parenthood and Employment, New York: Russell Sage Foundation.

Gornick J.C. and Meyers M.K. (2008) 'Creating Gender Egalitarian Societies: an Agenda for Reform' Politics and Society 36(3): 323-343.

Gornick J.C., Meyers M.K. and Ross K.E. (1997) 'Supporting the Employment of Mothers: Policy Variation across Fourteen Welfare States', Journal of European Social Policy 7(1): 45-70.

Haas L. (2003) 'Parental Leave and Gender Equality: Lessons from the European Union', Review of Policy Research 20(1): 89-114.

Haas L. and Hwang C.P. (2008) 'The Impact of Taking Parental Leave on Fathers' Participation in Childcare and Relationships with Children: Lessons from Sweden', Community, Work \& Family 11(1): 85-104.

Hantrais L. (2004) Family Policy Matters: Responding to Family Change in Europe, Bristol: Policy Press.

Hofferth S.L. and Curtin S.C. (2006) 'Parental Leave Statutes and Maternal Return to Work After Childbirth in The United States', Work and Occupations 33(1): 73-105.

Hudson J. and Kuhner S. (2009) 'Towards Productive Welfare? A Comparative Analysis of 23 OECD Countries', Journal of European Social Policy 19(1): 34-46.

Hudson J. and Kuhner S. (2010) 'Beyond the Dependent Variable Problem; the Methodological Challenges of Capturing Productive and Protective Dimensions of Social Policy, Social Policy \& Society 9(2): 167-179.

Huo J., Nelson M. and Stephens J.D. (2008) 'Decommodification and Activation in Social Democratic Policy: Resolving the Paradox', Journal of European Social Policy 18(1): 5-20.

Kamerman S.B., 2006, 'Parental Leave Policies: The Impact on Child Well-Being', in P. Moss and M. O’Brien (2006) 'International Review of Leave Policies and Related Research 2006', London: UK Department of Trade and Industry Research Series No. 57.

Kamerman S.B. and Moss P. (eds.) (2009) The Politics of Parental Leave Policies: Children, Parenting, Gender and the Labour Market, Bristol: Policy Press.

Knijn T. and Kremer M. (1997) 'Gender and the Caring Dimension of Welfare States: Toward Inclusive Citizenship', Social Politics: International Studies in Gender, State and Society 4(3): $328-361$.

Korpi W. (2000) 'Faces of Inequality: Gender, Class, and Patterns of Inequalities in Different Types of Welfare States', Social Politics: International Studies in Gender, State and Society 7(2): 127191.

Kremer M. (2007) How Welfare States Care: Culture, Gender and Citizenship In Europe, Amsterdam: Amsterdam University Press. 
Kvist J. (1999) 'Welfare Reform in the Nordic Countries in the 1990s: Using Fuzzy-Set Theory to Assess Conformity to Ideal Types, Journal of European Social Policy 9(3): 231-252.

Kvist J. (2007a) 'Exploring Diversity: Measuring Welfare State Change with Fuzzy-set Methodology, in Clasen J. and Siegel N.A. (eds.) Investigating Welfare State Change. The Dependant Variable Problem in Comparative Analysis, Cheltenham: Edward Elgar.

Kvist J. (2007b) 'Fuzzy Set Ideal Type Analysis', Journal of Business Research 60(5): 474-481.

Lammi-Taskula J. (2006) 'Nordic Men on Parental Leave: Can the Welfare State Change Gender Relations', in A.L. Ellingsaeter and A. Leira (eds.) Politicizing Parenthood in Scandinavia: Gender relations in Welfare States, Bristol: Policy Press.

Leira A. (1992) Welfare States and Working Mothers: the Scandinavian Experience, Cambridge: Cambridge University Press.

Leira A. (2002) Working Parents and the Welfare State: Family Change and Policy Reform in Scandinavia, Cambridge: Cambridge University Press.

Leitner S. (2003) 'Varieties of Familialism. The Caring Function of the Family in Comparative Perspective', European Societies 5(4): 353-375.

Leitner S. (2010) 'Germany Outpaces Austria in Childcare Policy: the Historical Contingencies of 'Conservative' Childcare Policy', Journal of European Social Policy 20(5):456-467.

Lewis J. (1992) 'Gender and the Development of Welfare Regimes', Journal of European Social Policy 2(3): 159-173.

Lewis J. (2001) 'The Decline of the Male Breadwinner Model: Implications for Work and Care', Social Politics: International Studies in Gender, State and Society 8(2): 152-169.

Lewis J. and Giullari S. (2005) 'The Adult Worker Model Family, Gender Equality and Care: The Search for New Policy Principles and the Possibilities and Problems of a Capabilities Approach', Economy and Society 34(1): 76-104.

Lister R. (1997) Citizenship: Feminist Perspectives, London: MacMillan Press.

Lutz H. (ed.) (2008) Migration and Domestic Work: A European Perspective on a Global Theme, Aldershot: Ashgate.

Morgan K.J. (2008) 'The Political Path to a Dual Earner/Dual Carer Society: Pitfalls and Possibilities', Politics and Society 36(3): 403-420.

Morgan K.J. and Zippel K. (2003) 'Paid to care: The Origins and Effects of Care Leave Policies in Western Europe', Social Politics: International Studies in Gender, State and Society 10(1): 4985.

Moss P. (2008) 'Making Parental Leave Parental', in P. Moss and M. Korintus (eds.) 'International Review of Leave Policies and Related Research 2008', London: UK Department of Trade and Industry Research Series No. 100. Available at: http://www.berr.gov.uk/files/file47247.pdf

Moss P. and Deven F. (eds.) (1999) Parental Leave: Progress or Pitfall? Brussels: NIDI/CBGS Publications.

Moss P. and O'Brien M. (2006) 'International Review of Leave Policies and Related Research 2006', London: UK Department of Trade and Industry Research Series No. 57. Available at: http://www.berr.gov.uk/files/file31948.pdf

Moss P. and Wall K. (2007) 'International Review of Leave Policies and Related Research 2007', London: UK Department of Trade and Industry Research Series No. 80. Available at:http://www.bis.gov.uk/files/file40677.pdf 
O'Connor J.S., Orloff A.S. and Shaver S. (1999) States, Markets, Families: Gender, Liberalism, and Social Policy in Australia, Canada, Great Britain, and the United States, Cambridge: Cambridge University Press.

Orloff A.S. (1993) 'Gender and the Social Rights of Citizenship: the Comparative Analysis of Gender Relations and Welfare States', American Sociological Review 58(3): 303-328.

Pronzato C.D. (2009) 'Return to Work after Childbirth: Does Parental Leave Matter in Europe?', Review of Economics of the Household 7(4): 341-360.

Ragin C.C. (2000) Fuzzy-set Social Science, Chicago, Chicago, IL: University of Chicago Press.

Ragin C.C. (2008) Redesigning Social Inquiry: Fuzzy Sets and Beyond, Chicago, IL: University of Chicago Press.

Ray R., Gornick J.C. and Schmitt J. (2010) 'Who Cares? Assessing Generosity and Gender Equality in Parental Leave Policy Designs in 21 Countries' Journal of European Social Policy 20(3): 196216.

Robeyns I. (2007) 'When Will Society be Gender Just?', in J. Browne (ed.) The Future of Gender, Cambridge: Cambridge University Press.

Rostgaard T. (2002) 'Setting Time Aside for the Father: Fathers Leave in Scandinavia', Community, Work and Family 5(3): 343-364.

Ruhm C.J.(1998) 'The Economic Consequences of Parental Leave Mandates: Lessons From Europe',. Quarterly Journal of Economics 113(1): 285-317.

Sainsbury D. (1996) Gender, Equality, and Welfare States, Cambridge: Cambridge University Press.

Saxonberg S. and Szelewa D. (2007) 'The Continuing Legacy of the Communist Legacy? The Development of Family Policies in Poland and the Czech Republic' Social Politics: International Studies in Gender, State and Society 14(3): 351-379.

Spiess C.K. and Wrohlich K. (2008) 'The Parental Leave Benefit Reform in Germany: Costs and Labour Market Outcomes of Moving Towards The Nordic Model', Population Research and Policy Review 27(5): 575-591.

Sundström M. and Duvander A.Z. (2002) 'Gender Division of Childcare and the Sharing of Parental Leave among New Parents in Sweden', European Sociological Review 18(4): 433-447.

Szelewa D. and Polakowski M.P. (2008) 'Who Cares? Changing Patterns of Childcare in Central and Eastern Europe', Journal of European Social Policy 18(2): 115-131.

Tronto J.C. (1993) Moral Boundaries: a Political Argument for an Ethic of Care, London: Routledge.

UNICEF (2008) 'The Child Care Transition', Florence: UNICEF Innocenti Research Centre.

Verloo M. (2010) 'Gender Equality Policies as Interventions in a Changing World', Keynote Lecture at the $2^{\text {nd }}$ Gender and Politics ECPR Conference $13^{\text {th }}$ January Budapest. Available at: http://www.ecprnet.eu/sg/ecpg/

Vis B. (2007) 'States of Welfare or States of Workfare? Welfare State Restructuring in 16 Capitalist Democracies, Policy and Politics 35(1): 105-122.

Waldfogel J. (2006) What Children Need, Cambridge, MA: Harvard University Press.

Wall K. (2007) 'Leave Policy Models and the Articulation of Work and Family in Europe: A Comparative Perspective', in P. Moss and K. Wall (eds.) 'International Review of Leave Policies and Related Research 2007', London: UK Department of Trade and Industry Research Series No. 80. Available at:http://www.bis.gov.uk/files/file40677.pdf

Weber M. (1949) The Methodology of the Social Sciences, New York: Free Press. 
${ }^{1}$ Additional data was collected for Norway, Iceland and Switzerland since these countries were not originally included in QUING.

${ }^{2}$ In 2010 the European Parliament proposed amendments to the Pregnant Workers Directive to extend paid maternity leave from 14 to 20 weeks and to introduce 2 weeks of fully-paid paternity leave. As the proposal is still under discussion, it is not reflected in this analysis.

${ }^{3}$ The crossover point (0.50) corresponds to the point where there is maximum ambiguity regarding whether a case is more in or more out of a set. As pointed out by Vis (2007: 111), this threshold is somewhat less important in continuous fuzzy sets than in limited value fuzzy-sets since the upper (1) and lower limit (0) that the researcher establishes should be justifiable as the point of maximum ambiguity. By establishing these thresholds, the researcher has already conceptually defined the borders between those different qualitative states of full membership and full non-membership. This may account for the common practice in research utilizing FSITA to explain only the upper and lower thresholds (Kvist, 1999, 2007b; Hudson and Kuhner, 2009; Vis, 2007).

${ }^{4}$ Since cases can only have membership in one configuration, and of the 31 cases analyzed only two (Germany and Luxembourg) do not achieve membership in one of the six theoretically relevant ideal types, 8 of the remaining 10 configurations are not only theoretically irrelevant but also empirically empty.

${ }^{5}$ In Italy, parents are individually entitled to 6 months of parental leave. However, their shared entitlement cannot exceed 10 months, or 11 if the father takes at least 3 months of leave. Accordingly, only 11 months were considered in the calculation of this index.

${ }^{6}$ The use of an alternative crossover point of 52 weeks leads to substantially similar results since only five countries shift membership from one ideal type to another. Italy, Ireland, and Netherlands would move from weak membership in the UUB to weak membership in the MB, showing that these countries might be characterized as a mix of these two models, while Sweden and Slovenia would weakly configu re respectively a FUC and CGP ideal.

7 Transferable maternity leaves are consistent with norms that place primary responsibility for childcare with the mother. Indeed, the transferable part of maternity leave remains a mother's right that she may decide to use or not. Therefore, the father has no individual entitlement to leave but must rely on a transfer from the mother. Conversely, the father's quota is per se a right of the father that he may or not decide to use.

${ }^{8}$ Bonus periods granted on the condition that fathers take some leave are considered to be reserved rights as they also represent entitlements that are lost if not used.

${ }^{9}$ Luxembourg configures a model $\left(\sim \mathrm{T}^{*} \mathrm{~V}^{*} \sim \mathrm{G}^{*} \sim \mathrm{F}\right)$ similar to the UUB $\left(\sim \mathrm{T}^{*} \mathrm{~V}^{*} \mathrm{G}^{*} \sim \mathrm{F}\right)$, but the gender gap in entitlements $(0.66)$ is slightly too low to achieve membership in such ideal type. Germany ( $\mathrm{T}^{*} \sim \mathrm{P}^{*} \mathrm{G}^{*} \mathrm{~F}$ ) differs instead from the male breadwinner configuration $\left(\mathrm{T}^{*} \sim \mathrm{P}^{*} \mathrm{G}^{*} \sim \mathrm{F}\right)$ because of the recent introduction of incentives for fathers' leave take-up.

${ }^{10}$ Several authors emphasize that Swedish family policy goes further in promoting gender equality than other Scandinavian countries (Earles, 2011; Rostgaard, 2002). Sweden is actually the European country with the second largest father's quota ( 2 months) and vast public campaigns to promote fathers' active engagement in childcare. Recent reforms include the introduction of a gender equality bonus (tax credit) intended to stimulate parents to share more equally parental leave. 